\title{
DOES STATE CONTROL AFFECT MANAGERIAL INCENTIVES? EVIDENCE FROM CHINA'S PUBLICLY LISTED FIRMS*
}

\author{
Chen Lin ${ }^{1}$, Dongwei Su \\ ${ }^{1}$ City University of Hong Kong, 83 Tat Chee Ave., Kowloon Tong, Hong Kong \\ 2 Jinan University, Guangzhou 510632, China

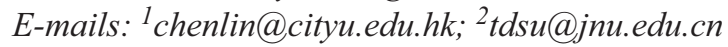 \\ Received 10 October 2008; accepted 5 September 2009
}

\begin{abstract}
Using data for 1203 publicly listed firms in China during 1999-2002, this paper empirically investigates whether and to what extent state control affects managerial incentives, including managerial compensation and CEO turnover. The paper finds that CEO turnover is negatively related to both current and lagged firm performance as measured by ROA and RPE (Relative Performance Evaluation) for non-state-controlled firms, while insensitive to performance measures for statecontrolled firms. In addition, CEO compensation is positively related to firm performance, but state ownership and control weaken this positive relation. Moreover, state control reduces the effectiveness of internal governance mechanisms such as the board of directors and supervisory committee. Overall, empirical results in the paper indicate that state ownership and control weaken managerial incentives and internal monitoring among publicly listed firms in China.
\end{abstract}

Keywords: managerial incentives, state control, corporate governance, partial privatization, China.

\section{Introduction}

In recent decades, worldwide privatization has drawn considerable research interest and generated a large number of theoretical and empirical studies concerning ownership, incentives and firm performance ${ }^{1}$. Megginson and Netter (2001) and Djankov and Murrell (2002) provide comprehensive surveys of over 200 empirical studies on privatization in both developed and emerging market economies, most of which focus on the differential performance between state-owned enterprises (SOEs) and privately-owned firms. Overall, existing evidence supports the proposition that private ownership is associated with better firm performance than state ownership is (e.g., Boubakri and Cosset 1998; D'Souza and Megginson 1999; Sun and Tong 2003; Tvaronavičiené and Kalašinskaitè 2005). A number of theories on privatization attribute the inefficiency of state ownership to weak incentives. For instance, Al- chian (1965) and Shleifer (1998) argue that dispersed owners of state firms (the citizens) make it difficult to write complete contracts linking manager's incentives to the returns from their decisions. In their survey of corporate governance, Shleifer and Vishny (1997) argue that SOEs are actually controlled by bureaucrats who have extremely concentrated control rights but no significant cash flow rights, since the latter is widely dispersed amongst the country's taxpayers. Bureaucrats' main concern is to achieve their political objectives and economic benefits, which are often quite different from the objective of maximizing SOE profits (Shleifer and Vishny 1994; Boycko et al. 1996). Therefore, state owners are thought to be unwilling to adopt incentives that are tied to performance; thus, bureaucrats are free to use firms to address their own goals (Cragg and Dyck 2003). Even bureaucrats who have shareholders' interest at heart have very weak incentives to invest the time and effort required to design

\footnotetext{
* Corresponding author is Dongwei Su. We are grateful to Mariana Bertrand for helpful discussions and Chunrong Ai, Sanford Berg, Joel Houston and Wei Shen for invaluable comments and suggestions. We also thank financial supports from the National Natural Science Foundation of China (Grant No. 70572065 and 70972081), China Ministry of Education (the Program for New Century Excellent Talents in University NCET-08-0614), the Guangdong Pearl River Scholar Fund, Guangdong Natural Science Foundation (Grant No. 9151063201000050) and the Guangdong Project of Key Research Institute of Humanities and Social Sciences at Universities (Grant No. 07JDTDXM79005).
} 
complete incentive contracts and monitor the performance of SOE managers, because the cost of doing so is much greater than the political/electoral payoff of modestly improving SOE performance (Megginson 2005). Furthermore, to safeguard economic rents, principals may use their power to protect SOEs from competition, bankruptcy and takeover through political mechanisms, such as soft budget constraints (Vickers and Yarrow 1991; Kornai 1998; Lin et al. 1998). As a result, the shield of state ownership weakens managerial incentives. Alas (2003) argues that countries with a socialist past have to deal with the satisfaction of needs at a lower level than traditional capitalist countries and this consequently influences managerial and workers' incentives. Tvaronavičienè (2004) provides a theoretical framework for formulating efficient state policy in incentive design for transition economies. However, Grossman and Hart (1986) and Cragg and Dyck (2003) argue that the exact form of ownership may not matter because managerial incentives within private enterprises can be imitated using appropriate contracts under state ownership. The tools that align incentives to performance are available to both private firms and SOEs. For instance, SOE Managers could be motivated to improve firm performance through incentive compensation based on achievement of certain targets, with poor-performing managers being punished through demotion or dismissals (Shirley and Xu 1998). In fact, Laffont and Tirole (1993) point out that theory alone is unlikely to be conclusive and econometric analyses are badly needed in this area.

Despite the importance of the issue, little is known about the relation between state control and managerial incentives due to limited information available on factors such as ownership structure, executive compensation and managerial turnover ${ }^{2}$. Our study builds on and extends existing literature by providing a detailed examination of the relation between state control and managerial incentives using a large sample of partially privatized listed firms in China. China was chosen as the context for this study for three reasons. First, China is the largest emerging economy in the world. In terms of GDP (adjusted using Purchasing Power Parity), China is the second largest economy behind only the U.S. China's domestic stock exchanges rank eleventh among the largest stock exchanges in the world (Allen et al. 2005). Second, China's share issue privatization (SIP) program is a nation-wide ongoing program that has raised more than 386 billion RMB in private investments. In China the state still retains about onethird of the shares in the listed firms, and is the largest shareholder in more than $20 \%$ of them. Thus, studying Chinese firms can provide evidence about ownership, control and incentives that are difficult to detect in the
U.S. or U.K. data. Third, the ongoing wage reforms in China transformed an egalitarian pay structure into an incentive-based compensation scheme through the adoption of "annual salary system", which provides an excellent context to examine the relation between state control and managerial incentives.

Tirole (2001) argues that managerial incentives are tied to financial performance in two ways. First, incentives derive from expected changes in compensation associated with financial performance (explicit incentives). Second, incentives could be a result of managers' fear of losing their job or autonomy (implicit incentives). Prendergast (1999) argues that dismissal threat is the most important form of nonlinear incentive contracts in which wages vary little with performance but poor performance is punished by dismissal. This may be especially the case in China, where salary and bonus are not the only way to reward managers. In a rent-seeking society, on-the-job perks, such as better housing, the use of cars, entertainment, restaurant meals, travel, diversion of assets and business opportunities, can be substantial (Chang and Wong 2004). Therefore, implicit incentives may matter more to managers of Chinese firms.

Following previous studies on managerial incentives (e.g. Kaplan 1994; Hadlock and Lumer 1997; Brickley and Van Horn 2002), we examine the impact of state control on the relation between CEO turnover and firm performance, as well as the relation between CEO compensation and firm performance. Our findings are as follows:

First, the probability of CEO turnover is negatively related to both current and lagged firm performance as measured by ROA, indicating that China's publicly listed firms provide clear profit incentives to CEOs so that poor-performing CEOs are more likely to be replaced. This result is robust to industry-adjusted relative performance evaluation (RPE) measures, suggesting that peer group benchmark performance is considered in the evaluation of management and the design of incentive schemes. However, when the sample is divided into two sub-samples that consist of state-controlled versus non-state-controlled firms, CEO turnover remains negatively related to current and lagged firm performance among non-state-controlled firms. In contrast, the likelihood of CEO turnover is not related to firm performance among state-controlled firms, indicating that state control weakens managerial incentives. This result is robust to model specifications (logit or probit models), performance measures (ROA or RPE) and turnover classification (overall turnover or forced turnover).

Second, CEO compensation is positively related to current and lagged firm performance. However, coef- 
ficient estimates of the interactive term between lagged performance and state control are all significantly negative, providing strong evidence that state control weakens pay-performance sensitivities.

Third, there is some evidence that state control weakens the effectiveness of board and supervisory committee. Specifically, among state-controlled firms, independent directors and outside supervisors do not have any significant impact on CEO turnover. In contrast, the number of independent directors and outside supervisors are positively related to the probability of CEO turnover among non-state-controlled firms. Furthermore, CEO duality reduces the probability of CEO turnover by a much larger magnitude among state-controlled firms than it does among non-state-controlled firms, suggesting that state-controlled firms are subject to more severe management entrenchment problems.

As Gupta (2005) points out, state is the controlling shareholder (percentage of shares greater than 20\%) in more than $18 \%$ of the publicly listed firms in 27 developed economies and in many transition economies. Thus, understanding the impact of state ownership on managerial incentives and firm performance is crucial to evaluate the success or failure of partial privatization. Our study adds to the literature on ownership, control and managerial incentives by providing robust evidence that state ownership and control weaken managerial incentives. In addition, our study complements several studies of corporate governance in China. For example, Xu and Wang (1999), Sun and Tong (2003) and Wei et al. (2005) all find that state ownership in the publicly listed firms in China has a negative impact on firm performance and market valuation. Our study, by focusing on the impact of state control on managerial incentives, provides empirical evidence that helps explain inefficiency of state ownership documented in these previous studies. As a result, our study also contributes to the literature on international corporate governance.

The rest of the paper is organized as follows. Section 2 describes the institutional context of this study. Section 3 provides information about our data and presents relevant summary statistics. Section 4 presents results and robustness tests. Section 5 concludes.

\section{SOE reforms, partial privatization and wage reforms in China}

Before the initiation of SOE reform in 1979, the Chinese state government owned all enterprises and operated them like production units of a single giant firm. Similar to other centrally planned economies, firms were not autonomous decision-making units. They were not financially independent and did not have responsibility for sales or pricing (Estrin 2002). The central government set production objectives and product prices. Enterprise managers were evaluated and compensated for following orders from the national or regional planning hierarchy and for subservience to political dogma (Mengistae and Xu 2004). A competitive managerial labor market, where managers are rewarded or punished in response to market forces and firm performance, almost did not exist (Groves et al. 1995). During this period, the central government collected all profits and distributed wages to workers at nationally determined pay rates. Managerial compensation was determined by factors such as the seniority, occupation, rank within the civil service bureaucrats and size of enterprises. Compensation was not related to either firm performance or individual contribution. Differences in pay were minimal and more symbolic than substantive, reflecting an egalitarian ideology. Since 1979, SOE reform in China has experienced three stages, which are briefly described below.

The first stage (1979-1983) focused on administrative decentralization and profit retention. To provide SOE managers with incentives and improve firm efficiency, SOEs were allowed to retain $3 \%$ of their profits. The second stage of reform (1983-1992) focused on the separation of government ownership from the control of SOE operations. SOE managers were given more autonomy to be in charge of enterprise operations after they promised a certain amount of tax (maximum tax rate was $55 \%$ ) to the government. In 1985, the Ministry of Labor (MOL) mandated that the budget allocated for wages be tied to the economic performance of SOEs. In 1987, the central government further increased managerial autonomy by allowing managers to retain some of their profits through the establishment of a Management Responsibility Contract System (MRCS). Under the MRCS, SOE managers were given a wide range of control rights in production, investment, sales, profits, personnel management, and distribution of bonuses and fringe benefits via contracts ( $\mathrm{Su} 2005$ ). Groves et al. (1995) find that MRCS not only enhanced managers' incentives and productivity, but also increased their compensation. An internal managerial labor market, where managers are promoted and compensated on the basis of their human capital and economic performance, had emerged at SOEs during this period. In 1992, the State Council issued a circular to start a pilot implementation of the "annual salary system" at 100 largest SOEs. This move was intended to further cope with inefficiency problems arising from insufficient managerial incentives. The new salary system allowed SOEs to set their internal wage structure within the overall budget guidelines established by the government. 
The third stage of the SOE reform started in 1993 following the third plenary session of the $14^{\text {th }}$ Party Congress. The goal of the reform was to transform and further improve the performance and efficiency of the SOEs through corporatization, adoption of profit making objectives and partial privatization. In the $15^{\text {th }}$ Party congress held in 1997, enterprise reform continued to be the main theme and the government called for continuous improvement by establishing a modern corporate governance system. Through SIPs, China first listed 10 former SOEs in the two stock exchanges (SHSE and SZSE) in 1990. Since then, the number of publicly listed firms has increased steadily. By the end of 2006, there were 1434 firms listed in the SHSE and SZSE, with a total market capitalization of 8.94 trillion Renminbi Yuan (about 1.15 trillion U.S. Dollars), representing approximately $42 \%$ of China's GDP. ${ }^{3}$

There are two distinct features of the enterprise reform in China in the 1990s. First, most listed firms have a dominant shareholder. In our sample, on average, the largest shareholder owns $44.5 \%$ (median is $43.8 \%$ ) of the total shares while the second largest shareholder owns about $8.4 \%$ (median is $5.1 \%$ ). The second feature is that state retains a significant amount of ownership in many listed firms, often as the largest shareholder. State, as represented by the State Asset Management Bureau (SAMB) and their local branches, owned about one-third of total shares and is the largest shareholder in about one-fourth of the listed firms. Firth et al. (2006) point out that, while the state gave substantial autonomy to managers of the listed firms, it was unwilling to give up control. Therefore, the dilemma of giving full managerial autonomy while maintaining state control of voting rights persisted till the end of our sample period. As a result, the unique ownership structure among China's listed firms provides a good laboratory to test the impact of state control on managerial incentives during partial privatization.

Parallel to the enterprise reform, wage reform was also pressed ahead by the central government. In 1994, the guidelines for publicly listed firms to set their own wage structure were further reduced to two criteria. One was that the growth rate of total wages must be lower than that of the net operating profit after tax. Another was that the growth rate of per capita wages must be lower than that of labor productivity. In recent years, the "annual salary system" has become increasingly popular because the central government has gradually recognized that compensation structure is one of the key elements in enhancing enterprise productivity and efficiency. In November 2003, the SAMB issued a circular to formally implement incentive-based an- nual salary systems among 189 SOEs directly owned by the central government. According to the circular, managerial compensation in the "annual salary system" consists of two major parts: fixed base salary and performance salary. This is very similar to the "salary plus bonus" compensation package offered by firms in developed market economies. In addition to the largest SOEs, the annual salary system has also been widely adopted by the publicly listed firms, most of which are partially privatized former SOEs. Fleisher and Wang (2003), Firth et al. (2006) document the adoption of incentive pay in different types of Chinese enterprises.

\section{Data and summary statistics}

The sample used in this study consists of 1203 firms listed on the SHSE or SZSE in China during 19992002. Most of the firms are partially privatized former SOEs, and 821 firms had gone public prior to 1999 . Our dataset is an unbalanced panel that consists of 4343 firm-year observations. All data are obtained from the Chinese Stock Market and Accounting Research (CSMAR) database, commercially available from Shenzhen GTA Information Technology Company and the University of Hong Kong. Table 1 provides summary statistics of key variables described below.

\subsection{Ownership structure}

The ownership structure of China's listed firms can be classified into three main categories: state shares, legal entity share and publicly tradable shares. State shares are retained by the SAMB of the central or local government branches and are not allowed to be publicly traded, although reforms have been initiated to free up these shares since May $2005^{4}$. Legal entity shares are held by domestic institutional investors including banks, securities companies, insurance companies, mutual funds, industrial enterprises, transportation and power companies, and some private enterprises. Similar to state shares, legal entity shares are also nontradable. However, there exist important differences between state ownership and legal entity ownership, which lead to different implications for managerial incentives. Sun and Tong (2003) point out that unlike SAMB, many legal entities have close business connections with listed firms in which they have ownership. Because legal entity shareholders benefit directly from listed firms' good performance and are hurt by their poor performance, they have incentives to be active in designing appropriate incentive contracts and engaging in active monitoring. Compared with either SAMB or individual shareholders, legal entities have more expert knowledge of firms in which they have 
Table 1. Summary statistics of key variables

The table reports the number of observations, mean, standard deviation, minimum value and maximum value for the key variables used in the analysis. Statistics are for a sample of 1203 firms listed on the Shanghai or Shenzhen stock exchanges in China during 1999 to 2002. CEO compensation is the annual total compensation (salary and bonus) received by CEO of the firm in specific year. CEO turnover is a dummy variable, which equals 1 if the employment of the CEO was terminated during the year, and zero otherwise. ROA is return on asset, the ratio of net income to total asset. Lag ROA is the one-year lagged ROA. Largest investor is the percentage of the shares held by the largest investor. State equals 1 if the largest investor is state, represented by the Bureau of National Asset Management, and zero otherwise. CEO age is the age (in years) of the CEO. Duality equals 1 when the CEO holds the board chair position and zero otherwise. CEO tenure is the number of the years the CEO has held the position till now. Board size is the number of directors on the board. Independent director is the number of independent directors on the board. No. of Supervisors is the number of supervisors on the supervisory committee. Outside supervisor is the number of outside supervisors on the supervisory committee. Firm size is the natural logarithm of the total assets. Marketization is the NERI (National Economics Research Institute, China) marketization index that measures the overall market development in each province in China, including market competition, government regulation, and the legal environment.

\begin{tabular}{|c|c|c|c|c|c|}
\hline Variable & Observation & Mean & Stdard Deviation & Minimum & Maximum \\
\hline CEO compensation & 2650 & 108724.4 & 162345.2 & 10000 & 6296667 \\
\hline CEO turnover & 4286 & 0.264 & 0.441 & 0 & 1 \\
\hline $\mathrm{ROA}$ & 4278 & 0.023 & 0.093 & -1.467 & 0.311 \\
\hline Lag ROA & 3917 & 0.030 & 0.093 & -1.467 & 0.377 \\
\hline Largest Investor & 4308 & 0.445 & 0.176 & 0.061 & 0.886 \\
\hline State & 4376 & 0.229 & 0.420 & 0 & 1 \\
\hline CEO age & 3214 & 47.445 & 7.425 & 26 & 70 \\
\hline Duality & 4318 & 0.189 & 0.392 & 0 & 1 \\
\hline CEO tenure & 4286 & 2.724 & 1.901 & 1 & 12 \\
\hline Board Size & 4319 & 9.633 & 2.538 & 4 & 24 \\
\hline Independent Director & 4311 & 0.822 & 1.184 & 0 & 6 \\
\hline No. of Supervisors & 4317 & 4.350 & 1.415 & 1 & 13 \\
\hline Outside Supervisor & 4148 & 1.817 & 1.508 & 0 & 10 \\
\hline Firm Size & 4292 & 20.920 & 0.874 & 17.389 & 26.632 \\
\hline Marketization & 4332 & 6.394 & 1.632 & 1.570 & 9.740 \\
\hline
\end{tabular}

shareholding interests and are better equipped to monitor managers through their influence on the board of directors. In contrast, public shares are held by the investment public and tradable on the two securities exchanges. Public shares are widely dispersed among millions of individual investors.

In our study, the sample is split into state-controlled firms (the controlling shareholder is the state, State = 1) and non-state-controlled firms (the controlling shareholder is not the State, State =0). Among nonstate-controlled firms, the largest shareholder is generally various types of legal entities. In our sample, $23 \%$ of the listed firms have state as their controlling shareholder (see Table 1).

Table 2 presents summary statistics of key variables for state-controlled and non-state-controlled firms, including ROA, CEO characteristics, board composition and the structure of the supervisory committee. We find that, on average, CEO compensation in state-controlled firms is lower than that in non-state-controlled firms. The difference is statistically significant at the $1 \%$ level. The average firm performance of non-statecontrolled firms $(\mathrm{ROA}=0.025)$ is significantly higher than that of the state-controlled firms $(\mathrm{ROA}=0.013)$. On average, CEOs for state-controlled firms are significantly older than those for non-state-controlled firms. The frequency for a CEO to serve as the chairman of the board (DUALITY) is significantly smaller for non-state-controlled firms. On average, state-controlled firms have larger supervisory committees while less outside committee members, indicating that supervisory committee is less independent among statecontrolled firms. 
Table 2. Summary statistics for state-controlled and non-state-controlled firms

State-controlled firms are firms of which the state is the largest shareholder, while non-state-controlled firms are firms of which the state is not the largest shareholder. In the non-state-controlled firms, the largest shareholder is generally various types of legal entities including industrial banks, securities companies, insurance companies, mutual funds, industrial enterprises, transportation and power companies, research institutes and other private business. CEO compensation is the annual total compensation (salary and bonus) received by CEO of the firm in specific year. CEO turnover is a dummy variable, which equals 1 if the employment of the CEO was terminated during the year, and zero otherwise. ROA is return on asset, the ratio of net income to total asset. Lag ROA is the one-year lagged ROA. Largest Investor is the percentage of the shares held by the largest investor. State equals 1 if the largest investor is state, represented by the Bureau of National Asset Management, and zero otherwise. CEO age is the age (in years) of the CEO. Duality equals 1 when the CEO holds the board chair position and zero otherwise. CEO tenure is the number of the years the CEO has held the position till now. Board size is the number of directors on the board. Independent Director is the number of independent directors on the board. No. of Supervisors is the number of supervisors on the supervisory committee. Outside Supervisor is the number of outside supervisors on the supervisor committee. Firm size is the natural logarithm of the total assets. Marketization is the NERI (National Economics Research Institute, China) marketization index that measures the overall market development in each province in China, including market competition, government regulation, and the legal environment.

\begin{tabular}{|c|c|c|c|c|c|c|c|}
\hline \multirow[b]{2}{*}{ Variable } & \multicolumn{3}{|c|}{ Non-State-Control } & \multicolumn{3}{|c|}{ State-Control } & \multirow{2}{*}{$\begin{array}{c}\mathrm{t}-\text { Statistics of } \\
\text { Difference in } \\
\text { Means }\end{array}$} \\
\hline & Obs. & Mean & $\begin{array}{c}\text { Stdard } \\
\text { Deviation }\end{array}$ & Obs. & Mean & $\begin{array}{c}\text { Stdard } \\
\text { Deviation }\end{array}$ & \\
\hline CEO compensation & 1973 & 113151.9 & 180253.5 & 677 & 95821.33 & 90956.9 & $3.236^{* * *}$ \\
\hline CEO turnover & 3307 & 0.268 & 0.443 & 979 & 0.249 & 0.433 & 1.180 \\
\hline ROA & 3304 & 0.025 & 0.088 & 974 & 0.013 & 0.109 & $3.280 * * *$ \\
\hline Lag ROA & 3006 & 0.033 & 0.091 & 911 & 0.023 & 0.101 & $2.652 * * *$ \\
\hline Largest Investor & 3310 & 0.446 & 0.178 & 998 & 0.440 & 0.169 & 0.982 \\
\hline CEO age & 2523 & 47.224 & 7.514 & 691 & 48.252 & 7.036 & $-3.352 * *$ \\
\hline Duality & 3320 & 0.183 & 0.387 & 998 & 0.209 & 0.407 & $-1.788^{*}$ \\
\hline CEO tenure & 3307 & 2.701 & 1.890 & 979 & 2.800 & 1.937 & -1.41 \\
\hline Board Size & 3328 & 9.645 & 2.555 & 991 & 9.596 & 2.480 & 0.533 \\
\hline Independent Director & 3315 & 0.817 & 1.183 & 996 & 0.837 & 1.187 & -0.470 \\
\hline No. of Supervisors & 3328 & 4.299 & 1.416 & 989 & 4.523 & 1.398 & $-4.413 * * *$ \\
\hline Outside Supervisor & 3205 & 1.896 & 1.538 & 943 & 1.547 & 1.370 & $6.680 * * *$ \\
\hline Firm Size & 3313 & 20.911 & 0.874 & 979 & 20.949 & 0.875 & -1.176 \\
\hline Marketization & 3335 & 6.378 & 1.641 & 997 & 6.449 & 1.600 & -1.233 \\
\hline
\end{tabular}

$*, * *$, and $* * *$ indicate statistical significance at the $10 \%, 5 \%$, and $1 \%$ levels for two-tailed tests, respectively.

\subsection{CEO turnover}

CEO turnover is a dummy variable, coded 1 when the employment of a CEO was terminated during the year, and 0 otherwise. There are 1130 CEO turnovers in our sample. Based on statements filed to China Securities Regulatory Committee (CSRC) and various newspaper announcements, CSMAR database classifies CEO turnover into the following 13 categories: (1) change of work assignment; (2) retirement; (3) expiration of contract; (4) change of share-controlling right; (5) resignation; (6) dismissal; (7) health reason; (8) personal reason; (9) corporate governance reform; (10) involved in litigation; (11) end of agency; (12) others; and (13) undisclosed. The top five disclosed reasons for CEO turnovers are change of work assignment (327 cases, $28.94 \%)^{5}$, expiration of contract (242 cases, $21.42 \%$ ), resignation (212 cases, $18.76 \%$ ), corporate governance reform (127 cases, $11.24 \%$ ), and dismissal (45 cases, $3.98 \%$ ). Table 3 reports detailed information about the distribution of CEO turnovers from 1999 to 2002.

Prior studies (e.g. Huson et al. 2004) emphasize the importance of distinguishing between forced and voluntary turnovers because only forced turnovers reflect the quality of monitoring. Clearly, CEO turnovers in our sample are not all forced. However, it is extremely difficult to separate forced and voluntary turnovers. 
Table 3. Distribution of CEO turnovers among publicly listed firms in China during 1999-2002

The CSMAR (Chinese Stock Market and Accounting Research) database classifies the reported reasons of CEO turnovers in China into 13 categories. There are 1130 CEO turnovers in our sample of 1203 firms during the period of 1999-2002. The table reports the frequency and percentage (in parentheses) distribution of CEO turnovers among the 13 categories of the reported reasons during each year and the entire sample period.

\begin{tabular}{|c|c|c|c|c|c|}
\hline Reported reasons & 1999 & 2000 & 2001 & 2002 & Total \\
\hline 1 Change of work assignment & $\begin{array}{c}82 \\
(32.41 \%)\end{array}$ & $\begin{array}{c}88 \\
(29.04 \%)\end{array}$ & $\begin{array}{c}99 \\
(34.86 \%)\end{array}$ & $\begin{array}{c}58 \\
(20.00 \%)\end{array}$ & $\begin{array}{c}327 \\
(28.94 \%)\end{array}$ \\
\hline 2 Retirement & $\begin{array}{c}7 \\
(2.77 \%)\end{array}$ & $\begin{array}{c}11 \\
(3.63 \%)\end{array}$ & $\begin{array}{c}2 \\
(0.70 \%)\end{array}$ & $\begin{array}{c}2 \\
(0.69 \%)\end{array}$ & $\begin{array}{c}22 \\
(1.95 \%)\end{array}$ \\
\hline 3 Expiration of contract & $\begin{array}{c}51 \\
(20.16 \%)\end{array}$ & $\begin{array}{c}73 \\
(24.09 \%)\end{array}$ & $\begin{array}{c}43 \\
(15.14 \%)\end{array}$ & $\begin{array}{c}75 \\
(25.86 \%)\end{array}$ & $\begin{array}{c}242 \\
(21.42 \%)\end{array}$ \\
\hline 4 Change of share-controlling right & $\begin{array}{c}18 \\
(7.11 \%)\end{array}$ & $\begin{array}{c}17 \\
(5.61 \%)\end{array}$ & $\begin{array}{c}1 \\
(0.35 \%)\end{array}$ & $\begin{array}{c}0 \\
(0.00 \%)\end{array}$ & $\begin{array}{c}36 \\
(3.19 \%)\end{array}$ \\
\hline 5 Resignation & $\begin{array}{c}23 \\
(9.09 \%)\end{array}$ & $\begin{array}{c}34 \\
(11.22 \%)\end{array}$ & $\begin{array}{c}53 \\
(18.66 \%)\end{array}$ & $\begin{array}{c}102 \\
(35.17 \%)\end{array}$ & $\begin{array}{c}212 \\
(18.76 \%)\end{array}$ \\
\hline 6 Dismissal & $\begin{array}{c}12 \\
(4.74 \%)\end{array}$ & $\begin{array}{c}9 \\
(2.97 \%)\end{array}$ & $\begin{array}{c}11 \\
(3.87 \%)\end{array}$ & $\begin{array}{c}13 \\
(4.48 \%)\end{array}$ & $\begin{array}{c}45 \\
(3.98 \%)\end{array}$ \\
\hline 7 Health reason & $\begin{array}{c}12 \\
(4.74 \%)\end{array}$ & $\begin{array}{c}7 \\
(2.31 \%)\end{array}$ & $\begin{array}{c}8 \\
(2.82 \%)\end{array}$ & $\begin{array}{c}7 \\
(2.41 \%)\end{array}$ & $\begin{array}{c}34 \\
(3.01 \%)\end{array}$ \\
\hline 8 Personal reason & $\begin{array}{c}0 \\
(0.00 \%)\end{array}$ & $\begin{array}{c}1 \\
(0.33 \%)\end{array}$ & $\begin{array}{c}1 \\
(0.35 \%)\end{array}$ & $\begin{array}{c}2 \\
(0.69 \%)\end{array}$ & $\begin{array}{c}4 \\
(0.35 \%)\end{array}$ \\
\hline 9 Corporate governance reform & $\begin{array}{c}41 \\
(16.21 \%)\end{array}$ & $\begin{array}{c}51 \\
(16.83 \%)\end{array}$ & $\begin{array}{c}28 \\
(9.86 \%)\end{array}$ & $\begin{array}{c}7 \\
(2.41 \%)\end{array}$ & $\begin{array}{c}127 \\
(11.24 \%)\end{array}$ \\
\hline 10 Litigation & $\begin{array}{c}0 \\
(0.00 \%)\end{array}$ & $\begin{array}{c}4 \\
(1.32 \%)\end{array}$ & $\begin{array}{c}1 \\
(0.35 \%)\end{array}$ & $\begin{array}{c}0 \\
(0.00 \%)\end{array}$ & $\begin{array}{c}5 \\
(0.44 \%)\end{array}$ \\
\hline 11 End of agency & $\begin{array}{c}3 \\
(1.19 \%)\end{array}$ & $\begin{array}{c}5 \\
(1.65 \%)\end{array}$ & $\begin{array}{c}0 \\
(0.00 \%)\end{array}$ & $\begin{array}{c}0 \\
(0.00 \%)\end{array}$ & $\begin{array}{c}8 \\
(0.71 \%)\end{array}$ \\
\hline 12 Other & $\begin{array}{c}0 \\
(0.00 \%)\end{array}$ & $\begin{array}{c}0 \\
(0.00 \%)\end{array}$ & $\begin{array}{c}8 \\
(2.82 \%)\end{array}$ & $\begin{array}{c}2 \\
(0.69 \%)\end{array}$ & $\begin{array}{c}10 \\
(0.88 \%)\end{array}$ \\
\hline 13 Undisclosed reason & $\begin{array}{c}4 \\
(1.19 \%)\end{array}$ & $\begin{array}{c}3 \\
(0.99 \%)\end{array}$ & $\begin{array}{c}29 \\
(10.21 \%)\end{array}$ & $\begin{array}{c}22 \\
(7.59 \%)\end{array}$ & $\begin{array}{c}58 \\
(5.13 \%)\end{array}$ \\
\hline Total & 253 & 303 & 284 & 290 & 1130 \\
\hline No. of firms & 918 & 1054 & 1126 & 1188 & 4286 \\
\hline
\end{tabular}

Firms usually are reluctant to reveal genuine reasons of CEO turnover. In particular, Chinese culture emphasizes harmony and preserving face in interpersonal and social relationships. Outright dismissal is perceived as a huge embarrassment and causes people to lose face. Thus, the reported reasons do not always reveal the true cause of CEO turnover. Huson et al. (2004) use whether an outgoing $\mathrm{CEO}$ is under the age of 60 years as a criterion to identify forced turnover. This classification is reasonable in the U.S. context, because serving as the CEO of a large firm is usually the last stage of one's career and almost all CEOs choose not to retire until they are at least 60 years old. However, this classification may not be applicable in the Chinese context. In fact, about $94 \%$ of CEOs in our sample left the position before reaching the age of 60 years, which is also the ordinary retirement age. It is difficult to argue that all these CEOs were forced out.

Given the special context of China, our study analyzes the turnover for all CEOs and tests the robustness of results by tracking the post-turnover employment of outgoing CEOs in our sample ${ }^{6}$. We find that in 654 out of 1130 cases, outgoing CEO remains an executive of the company (board chair, vice board chair, director, executive president and supervisory committee chair, etc.). We exclude these cases as forced turnover. For 
the remaining turnovers, we exclude turnovers with reported reasons as retirement ( 5 cases), health (13 cases), change of controlling shareholder (27 cases) and legal disputes ( 3 cases). We then exclude turnovers with outgoing CEOs more than 60 years old (14 cases). Eventually, we identify 372 turnovers as forced turnovers in our sample. Using this classification, we conduct robustness tests in section 4.3.

\subsection{Executive compensation}

We use total annual compensation, including base salary and bonus, to calculate CEO pay ${ }^{7}$. We do not consider stock options or stock ownership because they are rare among Chinese executives. In fact, none of the listed firms had used stock options as part of the executive compensation package by the end of 2002 . Executive stock ownership stems from the so-called employee shares and only represents less than $0.01 \%$ of total shares outstanding, which is much less than the fractional managerial shareholding in developed market economies $^{8}$. More importantly, shares held by executives are not tradable and hence not tied to managerial performance. Even if a manager performs well and gets promoted, his stock ownership usually does not change, at least in our sample. Furthermore, CSRC issued a circular to cease the issuance of employee shares in 1998.

Table 4 presents summary statistics of CEO compensation across industries and years. As shown in the table, CEO compensation increases over time in almost all industries. The average CEO compensation increases from RMB 89,882 in the year 2000 to RMB 128,414 in the year 2002, representing a $43 \%$ increase. Information technology industry has the highest average CEO compensation (RMB 162,392), followed by public services (RMB 152,726) and real estate (RMB 149,908).

\subsection{Performance measures}

Firm performance is measured by ROA (return on asset) and RPE (relative performance evaluation) ${ }^{9}$. ROA is a widely used measure of accounting profitability in corporate governance studies (e.g. Huson et al. 2001; Brickley and Van Horn 2002). Parrino (1997) points out that RPE, calculated as firm-specific ROA minus the median ROA of an industry, can filter out common factors within such as shocks that are beyond managers' control and thus provide more precise information about firm performance. We use both ROA and RPE as performance measures.

\subsection{Board characteristics}

A well-functioning board of directors is widely regarded as an important internal corporate governance mechanism for CEO compensation and turnover. How- ever, whether or not boards are effective has always been a controversial issue. Su (2005) argues that board directors in China's publicly listed firms are largely selected through political and administrative processes rather than endogenously chosen in competitive managerial labor markets. Therefore, the impact of board structure on managerial incentives in China's listed firms is an empirical question worthy of exploration. We use the following three variables to characterize board of directors. The first variable is board size ${ }^{10}$. Jensen (1993) and Yermack (1996) argue that larger boards are less effective in monitoring management and more susceptible to the influence of CEOs. The second variable is the number of independent or outside directors, defined as directors who are not members of the management team ${ }^{11}$. Fama and Jensen (1983) argue that independent directors generally care about their reputations and social status, thus have incentives to monitor management. The third variable is CEO duality, which equals 1 if a CEO is also the board chair and 0 otherwise. Dalton and Kesner (1997) argue that holding board chair enables CEOs to exert more control over board agenda and decisions, which weakens the governance function of the board.

\subsection{The structure of the supervisory committee}

According to China's Company Law, publicly listed firms must establish a supervisory committee consisting of shareholder representatives and employee representatives in appropriate proportions. The duties of supervisors are to scrutinize decisions made by managers, directors and other senior personnel, review and audit reports provided by directors, safeguard firm's assets, and resolve disputes between shareholders and directors. In practice, supervisory committees are headed by Communist Party leaders of a firm and do not have finance or audit sub-committee. More importantly, it is only equipped with the right of supervision, without the right to select managers and directors and to veto the decision of the board or management. Hence, the power of supervisory committees is quite limited. We use the size of the supervisory committee and the number of outside supervisors to characterize supervisory committees.

\subsection{Marketization index}

One special feature of Chinese economy is the imbalanced regional development. The differential level of economic development, market competitiveness and legal environment can exert significant impact on the quality of corporate governance. To address this issue, we use the NERI (National Economics Research Institute of China) provincial marketization index compiled by Fan and Wang (2004) and a set of provincial dummies in our empirical analysis. 
Table 4. Summary Statistics of CEO Compensation by Industry and Year (Unit: RMB yuan)

\begin{tabular}{|c|c|c|c|c|c|}
\hline \multirow{3}{*}{$\begin{array}{l}\text { Industry } \\
\text { Farming, Forestry, Animal } \\
\text { Husbandry, and Fishery }\end{array}$} & \multicolumn{5}{|c|}{ FISCAL YEAR } \\
\hline & \multicolumn{2}{|r|}{2000} & \multirow{2}{*}{$\begin{array}{c}2001 \\
65927.152\end{array}$} & \multirow{2}{*}{$\frac{2002}{138634.42}$} & \multirow{2}{*}{$\begin{array}{c}\text { Total } \\
89776.349\end{array}$} \\
\hline & mean & 63576.571 & & & \\
\hline & std. & 37310.443 & 46017.554 & 202374.54 & 125736.61 \\
\hline & Obs. & 21 & 22 & 22 & 65 \\
\hline \multirow{3}{*}{$\begin{array}{l}\text { Mining, and Oil and Gas } \\
\text { Extraction }\end{array}$} & mean & 62100.047 & 61103.879 & 88888.301 & 70966.077 \\
\hline & std. & 38527.828 & 46515.118 & 63721.608 & 51113.334 \\
\hline & Obs. & 10 & 11 & 11 & 32 \\
\hline \multirow[t]{3}{*}{ Manufacturing } & mean & 80640.778 & 95566.571 & 111204.47 & 96171.477 \\
\hline & std. & 117029.91 & 285862.31 & 117836.17 & 192048.21 \\
\hline & Obs. & 488 & 518 & 525 & 1531 \\
\hline \multirow[t]{3}{*}{ Utilities } & mean & 75149.367 & 97712.577 & 134182.78 & 102666.59 \\
\hline & std. & 53206.961 & 88329.101 & 131537.88 & 99025.455 \\
\hline & Obs. & 33 & 33 & 34 & 100 \\
\hline \multirow[t]{3}{*}{ Construction } & mean & 149258.27 & 118201.19 & 148842.12 & 138767.19 \\
\hline & std. & 182683.62 & 60833.004 & 101318.83 & 123953.09 \\
\hline & Obs. & 17 & 17 & 17 & 51 \\
\hline \multirow[t]{3}{*}{ Transportation and Warehousing } & mean & 107637.62 & 113988.85 & 148467.11 & 124317.67 \\
\hline & std. & 81873.225 & 77865.803 & 92164.669 & 85407.577 \\
\hline & Obs. & 29 & 35 & 35 & 99 \\
\hline \multirow[t]{3}{*}{ Information Technology } & mean & 145727.9 & 160777.45 & 179596.98 & 162392.5 \\
\hline & std. & 124487.58 & 119348.01 & 119199.42 & 120899.6 \\
\hline & Obs. & 45 & 47 & 48 & 140 \\
\hline \multirow[t]{3}{*}{ Wholesale and Retail Trade } & mean & 81930.79 & 106238.99 & 137567.19 & 109737.9 \\
\hline & std. & 61741.633 & 79440.053 & 106496.1 & 88117.814 \\
\hline & Obs. & 73 & 80 & 83 & 236 \\
\hline \multirow[t]{3}{*}{ Real Estate } & mean & 105473.77 & 153345.68 & 184199.61 & 149907.6 \\
\hline & std. & 95057 & 122700.94 & 148846.07 & 127979.48 \\
\hline & Obs. & 22 & 25 & 26 & 73 \\
\hline \multirow[t]{3}{*}{ Public Service } & mean & 137642.19 & 137325.22 & 181488.01 & 152726.45 \\
\hline & std. & 144508.92 & 127459.07 & 148519.65 & 140468 \\
\hline & Obs. & 31 & 35 & 35 & 101 \\
\hline \multirow[t]{3}{*}{ Communication and Culture } & mean & 102619.5 & 105890.48 & 113187.81 & 107463.25 \\
\hline & std. & 42774.977 & 71533.248 & 78570.17 & 63774.949 \\
\hline & Obs. & 6 & 7 & 7 & 20 \\
\hline \multirow[t]{3}{*}{ Conglomerates } & mean & 96785.11 & 116322.21 & 150086.5 & 121681.97 \\
\hline & std. & 65277.123 & 82654.323 & 110873.14 & 91119.636 \\
\hline & Obs. & 68 & 71 & 73 & 212 \\
\hline \multirow[t]{3}{*}{ Total } & mean & 89882.275 & 104933.81 & 128414.4 & 108249.51 \\
\hline & std. & 108739.41 & 225497.5 & 121780 & 162201.83 \\
\hline & Obs. & 843 & 901 & 916 & 2660 \\
\hline
\end{tabular}


The marketization index characterizes the progress of transition towards market economy for 31 provinces and special administrative regions and encompasses various indicators such as the extent of government intervention, the degree of market competition, the development of product and factor markets and the strength of legal environment. Fan and Wang (2004) transform the value of the above indicators into $0-10$, with higher values being indicative of higher degree of marketization, and then use principal component analysis to determine the weight for each indicator. A higher marketization index is associated with less government intervention and more regional economic freedom.

\subsection{Other control variables}

We use the age of CEOs, CEO tenure (the number of the years the CEO has held the position till to date), firm size (the natural logarithm of the total assets), and industry and year dummies as other control variables throughout our empirical analysis.

\section{Empirical evidence on CEO turnover and firm performance}

\subsection{Basic models}

We employ Probit models to examine the relation between state ownership and CEO turnover (Table 5). The probability/likelihood function of CEO turnover can be expressed as:

$\operatorname{Pr}($ turnover $)=f($ performance, largest

shareholder shareholding, CEO age, CEO duality, CEO tenure, board structure, supervisory committee structure, firm size, marketization, industry dummies, province dummies, year dummies),

where $f(\cdot)$ is the standard normal cumulative distribution (cdf) in the Probit model, which can be expressed as:

$$
f(z)=\Phi(z)=\int_{-\infty}^{z} \phi(v) d v,
$$

where $\phi(\cdot)$ is the standard normal density.

To test for the effect of firm types on the turnoverperformance sensitivities, we estimate a Probit model, formulated as $\operatorname{Pr}($ turnover $)=f($ performance, type, type $\times$ performance, controls), where type is a binary variable representing underlying characteristics such as state-controlled versus non-state- controlled firms (Powers 2006). However, as Ai and Norton (2003) point out, in non-linear models such as Probit models, the marginal effect of an interaction variable is quite complex. Specifically, consider a Probit model with an interactive term:

$E\left[y / x_{1}, x_{2}, X\right]=\Phi\left(\beta_{1} x_{1}+\beta_{2} x_{2}+\beta_{12} x_{1} x_{2}+X \beta\right)=\Phi(\cdot)$.

The interactive effect can be expressed as:

$\frac{\partial^{2} \Phi(\cdot)}{\partial x_{1} \partial x_{2}}=\beta_{12} \Phi^{\prime}(\cdot)+\left(\beta_{1}+\beta_{12} x_{2}\right)\left(\beta_{2}+\beta_{12} x_{1}\right) \Phi^{\prime \prime}(\cdot)$.

Ai and Norton (2003) summarize three implications for Probit models based on equation (3) and (4). First, the interaction effect could be zero, even if $\beta_{12} \neq 0$. Second, the statistical significance of the interaction effect cannot be tested using simple t-test on the coefficient $\beta_{12}$. Third, the interactive effect is conditional on independent variables and may have different signs when independent variables take different values. The aforementioned three implications are usually overlooked in empirical studies ${ }^{12}$. To apply the approach proposed by Ai and Norton (2003), we follow Powers (2005) and estimate a Probit regression using the full sample. Then we split the sample into state-controlled and nonstate-controlled firms, and estimate Probit regressions for each sub-sample. Finally, we compute and contrast marginal effects of performance on turnover for two types of firms.

Table 5 contains empirical results for Probit models ${ }^{13}$. As shown in the table, CEO turnover is negatively related to firm performance. The coefficients of current and lagged performance are statistically significantly negative at the $1 \%$ level, suggesting that high (low) performance decreases (increases) the probability of CEO turnover. Specifically, on average, a decrease in ROA or lagged ROA by 10 percentage points increases the probability of CEO turnover by 0.041 and 0.056 , respectively. This finding indicates that China's listed firms provide clear profit incentives to CEOs so that poor-performing CEOs are more likely to be replaced.

Ownership concentration, as measured by the largest shareholder shareholdings, reduces the probability of CEO turnover. As we have argued in Section 2, there is usually one overwhelmingly large shareholder with substantial controlling power in listed firms. One way for large shareholders to pursue their private interests is to exert control over the selection of managers and make sure that top managers represent their interests ${ }^{14}$. When firms are dominated by large shareholders who seek their private interests, the risk of CEO turnover will likely be decoupled from firm performance and influenced by how well CEOs serve the private interests 
Table 5. Probit regression analysis of CEO turnover at the publicly listed firms in China

The models are estimated using firm-level data of the firms listed on the Shanghai or Shenzhen stock exchanges in China during the period 1999-2002. State-controlled firms are firms of which the state is the largest shareholder, while non-statecontrolled firms are firms of which the state is not the largest shareholder. The dependent variable, CEO turnover, equals 1 if the employment of the $\mathrm{CEO}$ was terminated during the year, and zero otherwise. Performance is measured with ROA. $\mathrm{Lag}$ (performance) is the one-year lagged performance (ROA). Largest Investor is the percentage of the shares held by the largest investor. CEO age is the age (in years) of the CEO. Duality equals 1 when the CEO holds the board chair position, and zero otherwise. CEO tenure is the number of the years the CEO has held the position till now. Board size is the number of directors on the board. Independent Director is the number of independent directors on the board. No. of Supervisors is the number of supervisors on the supervisory committee. Outside supervisor is the number of outside supervisors on the supervisory committee. Firm size is the natural logarithm of the total assets. Marketization is the NERI (National Economics Research Institute, China) marketization index that measures the overall market development in each province in China, including market competition, government regulation, and the legal environment. Industry, province and year dummies are included in the models, but their coefficients are not reported. $P$-values for two-tailed tests that the coefficient estimates equal zero are reported. The $P$-values are estimated using robust stand errors that account for potential heteroskedasticity and time series autocorrelation within each company (clustering by company). The coefficient estimates are transformed to represent the marginal effects evaluated at the means of the independent variables from the Probit regression. The marginal effect of a dummy variable is calculated as the discrete change in the expected value of the dependent variable as the dummy variable changes from 0 to 1 .

\begin{tabular}{|c|c|c|c|c|c|c|}
\hline \multirow[t]{2}{*}{ Independent Variables } & \multicolumn{2}{|c|}{ Full Sample } & \multicolumn{2}{|c|}{ State-Control } & \multicolumn{2}{|c|}{ Non-State-Control } \\
\hline & Coefficient & $P$-Value & Coefficient & $P$-Value & Coefficient & $P$-Value \\
\hline Performance & $-0.408 * * *$ & 0.000 & -0.308 & 0.167 & $-0.513 * * *$ & 0.001 \\
\hline Lag Performance & $-0.555^{* * *}$ & 0.002 & -0.303 & 0.307 & $-0.674 * * *$ & 0.000 \\
\hline Largest Investor & $-0.173^{* * *}$ & 0.005 & $-0.260 *$ & 0.094 & $-0.189 * * *$ & 0.006 \\
\hline CEO age & $0.008 * * *$ & 0.000 & $0.010 * * *$ & 0.006 & $0.007 * * *$ & 0.000 \\
\hline Duality & $-0.217 * * *$ & 0.000 & $-0.364 * * *$ & 0.000 & $-0.184 * * *$ & 0.000 \\
\hline CEO tenure & $-0.011 * *$ & 0.047 & -0.007 & 0.577 & -0.009 & 0.149 \\
\hline Board Size & $-0.010 * *$ & 0.019 & -0.015 & 0.141 & $-0.009^{*}$ & 0.054 \\
\hline Independent Director & $0.034^{* *}$ & 0.018 & -0.001 & 0.988 & $0.041^{* *}$ & 0.011 \\
\hline No. of Supervisors & -0.007 & 0.429 & 0.017 & 0.399 & -0.012 & 0.200 \\
\hline Outside Supervisor & 0.019 ** & 0.013 & -0.006 & 0.749 & $0.028 * * *$ & 0.002 \\
\hline Firm Size & $-0.028^{*}$ & 0.055 & $-0.061^{*}$ & 0.086 & -0.015 & 0.327 \\
\hline Marketization & 0.05 & 0.155 & 0.039 & 0.723 & 0.048 & 0.214 \\
\hline Industry Dummies & Yes & & Yes & & Yes & \\
\hline Province Dummies & Yes & & Yes & & Yes & \\
\hline Year Dummies & Yes & & Yes & & Yes & \\
\hline Log-Likelihood & -1524.96 & & -319.86 & & -1277.3 & \\
\hline Pseudo R-square & 0.086 & & 0.167 & & 0.086 & \\
\hline Observations & 2677 & & 575 & & 2097 & \\
\hline
\end{tabular}

$*, * *$, and $* * *$ indicate statistical significance at the $10 \%, 5 \%$, and $1 \%$ levels for two-tailed tests, respectively.

of large shareholders ${ }^{15}$. A higher level of ownership is associated with more power of control, and increases the probability that CEOs will cater to the private interests of the largest shareholders. As a result, CEO turnover is negatively related to the share ownership of the largest shareholders.
Regarding the board structure, the coefficients of duality are negative and statistically significant at the $1 \%$ level, supporting the notion that holding the board chair position by the CEO weakens monitoring and incentive effects. Specifically, CEO duality reduces the probability of CEO turnover by 0.217 . Consistent to 
our expectation, CEO turnover is negatively related to board size but positively related to the number of independent directors. One extra independent director on the board increases the probability of CEO turnover by 0.034 , after controlling for firm performance and other variables. The results provide some evidence that independent directors play a positive role in monitoring CEOs. Regarding the supervisory committee, the size of the supervisory committee does not exert significant impact on CEO turnover. Similar to the independent director, the number of outside supervisors is positively related to the probability of CEO turnover, although the magnitude is relatively small. This result indicates that outside supervisors only exert modest impacts on improving internal incentive and monitoring schemes. Furthermore, we find that the coefficient for firm size is negative and statistically significant at the $5 \%$ level, suggesting that the likelihood of CEO turnover at larger firms is lower than at smaller firms. Finally, CEO turnover is positively related to CEO age but negatively related to CEO tenure, both are statistically significant at the $1 \%$ level.

When the sample was split into state-controlled and non-state-controlled firms, CEO turnover is not related to either current or lagged firm performance for state-controlled firms. In contrast, CEO turnover is significantly negatively related to current and lagged ROA at the $1 \%$ level for non-state-controlled firms. In particular, a decrease of ROA by 10 percentage points increases the probability of CEO turnover by 0.0513 and a decrease in lagged ROA by 10 percentage points increases the probability of CEO turnover by 0.0674 .

Furthermore, the effect of board composition and supervisory committee on CEO turnover differs significantly between state-controlled and non-state-controlled firms. For example, CEO duality reduces the probability of CEO turnover in both types of firms, but the magnitude of the impact is much stronger for statecontrolled firms. The coefficients for the number of independent directors and outside supervisors are positively related to CEO turnover for non-state-controlled firms, but are insignificant for state-controlled firms. Overall, the evidence indicates that state-controlled firms have more severe management entrenchment problems, weaker internal governance mechanisms and less effective managerial incentive schemes.

\subsection{Relative performance evaluation and CEO turnover}

To test the robustness of the findings in Section 4.1, we estimate Probit regressions using industry- adjusted ROA (calculated as the difference between firm ROA and the industry median ROA) as an alternative meas- ure of firm performance. Estimation results are illustrated in Table 6.

As shown in Table 6, empirical results using the RPE variable are similar to those using ROA. For the full sample, the coefficients for RPE are negative and statistically significant at the $1 \%$ level. On average, a decrease in RPE and lagged RPE by 10 percentage points increases the probability of CEO turnover by 0.04 and 0.057 , respectively. In addition, a 10-percentage-point increase in ownership concentration reduces the probability of CEO turnover by 0.019 . CEO turnover is positively related to CEO age while negatively related to $\mathrm{CEO}$ tenure. $\mathrm{CEO}$ duality reduces the probability of $\mathrm{CEO}$ turnover by 0.22 . Controlling for the firm performance and other variables, one additional board member decreases the probability of CEO turnover by 0.009 while one additional independent director increases the probability of CEO turnover by 0.034 . The supervisory committee size does not have significant impact on CEO turnover. However, one additional outside supervisory committee member increases the probability of CEO turnover by 0.019 . Moreover, firm size is negatively related to the probability of CEO turnover.

A comparison of estimation results for state-controlled versus non-state-controlled firms reinforces our previous findings. The likelihood of CEO turnover is not related to either current or lagged RPE for state-controlled firms, but is significantly negatively related to current and lagged RPE for non-state-controlled firms. A decrease in RPE or lagged RPE by 10 percentage points increases the probability of CEO turnover by 0.049 and 0.065 , respectively. In addition, board and supervisory committee do not appear to affect managerial turnover among state-controlled firms as the coefficients for the number of independent directors and outside supervisors are insignificant. In contrast, the number of independent directors and outside supervisors are significantly and positively related to CEO turnover for non-state-controlled firms. Furthermore, CEO duality reduces the probability of CEO turnover by a much larger magnitude for state-controlled firms than it does for non-state-controlled firms, suggesting that state-controlled firms have more severe managerial entrenchment problems. Overall, the above results bolster our previous findings that state control weakens managerial incentives and internal monitoring.

\subsection{Forced versus voluntary turnover}

Our empirical results have shown that firm performance is negatively related to the likelihood of CEO turnover, and that state control weakens managerial incentives and internal monitoring. However, as we 
Table 6. Relative performance evaluation (RPE) and CEO turnover at the publicly listed firms in China

The models are estimated using firm-level data of the firms listed on the Shanghai or Shenzhen stock exchanges in China during the period 1999-2002. State-control firms are firms of which the state is the largest shareholder, while non-statecontrol firms are firms of which the state is not the largest shareholder. The dependent variable, CEO turnover, equals 1 if the employment of the CEO was terminated during the year, and zero otherwise. Performance is measured with RPE: industry median adjusted ROA (firm specific ROA minus the industry median ROA). Lag performance is the one-year lagged industry median adjusted ROA. Largest Investor is the percentage of the shares held by the largest investor. CEO age is the age (in years) of the CEO. Duality equals 1 when the CEO holds the board chair position, and zero otherwise. $\mathrm{CEO}$ tenure is the number of the years the CEO has held the position till now. Board size is the number of directors on the board. Independent Director is the number of independent directors on the board. No. of Supervisors is the number of supervisors on the supervisory committee. Outside Supervisor is the number of outside supervisors on the supervisory committee. Firm size is the natural logarithm of the total assets. Marketization is the NERI (National Economics Research Institute, China) marketization index that measures the overall market development in each province in China, including market competition, government regulation, and the legal environment. Industry, province and year dummies are included in the models, but their coefficients are not reported. $P$-values for two-tailed tests that the coefficient estimates equal zero are reported. The $P$-values are estimated using robust stand errors that account for potential heteroskedasticity and time series autocorrelation within each company (clustering by company). The coefficient estimates are transformed to represent the marginal effects evaluated at the means of the independent variables from the Probit regression. The marginal effect of a dummy variable is calculated as the discrete change in the expected value of the dependent variable as the dummy variable changes from 0 to 1 .

\begin{tabular}{|c|c|c|c|c|c|c|}
\hline \multirow[t]{2}{*}{ Independent Variables } & \multicolumn{2}{|c|}{ Full Sample } & \multicolumn{2}{|c|}{ State-Control } & \multicolumn{2}{|c|}{ Non-State-Control } \\
\hline & Coefficient & $P$-Value & Coefficient & $P$-Value & Coefficient & $P$-Value \\
\hline Performance & $-0.401 * * *$ & 0.000 & -0.284 & 0.184 & $-0.491 * * *$ & 0.001 \\
\hline Lag Performance & $-0.570 * * *$ & 0.002 & -0.395 & 0.286 & $-0.653 * * *$ & 0.000 \\
\hline Largest Investor & $-0.192 * * *$ & 0.002 & $-0.260^{*}$ & 0.092 & $-0.201 * * *$ & 0.004 \\
\hline CEO age & $0.008 * * *$ & 0.000 & $0.010^{* * *}$ & 0.005 & $0.007 * * *$ & 0.000 \\
\hline Duality & $-0.220 * * *$ & 0.000 & $-0.365^{* * *}$ & 0.000 & $-0.184 * * *$ & 0.000 \\
\hline CEO tenure & $-0.010 *$ & 0.065 & -0.007 & 0.562 & -0.009 & 0.144 \\
\hline Board Size & $-0.009 * *$ & 0.024 & -0.016 & 0.125 & $-0.009 *$ & 0.065 \\
\hline Independent Director & $0.034^{* *}$ & 0.017 & 0.000 & 0.993 & $0.042 * * *$ & 0.009 \\
\hline No. of Supervisors & -0.007 & 0.396 & 0.017 & 0.390 & -0.012 & 0.192 \\
\hline Outside Supervisor & $0.019 * *$ & 0.016 & -0.007 & 0.713 & $0.027 * * *$ & 0.002 \\
\hline Firm Size & $-0.031 * *$ & 0.033 & $-0.064 *$ & 0.070 & -0.018 & 0.251 \\
\hline Marketization & 0.048 & 0.177 & 0.036 & 0.743 & 0.047 & 0.224 \\
\hline Industry Dummies & Yes & & Yes & & Yes & \\
\hline Province Dummies & Yes & & Yes & & Yes & \\
\hline Year Dummies & Yes & & Yes & & Yes & \\
\hline Log-Likelihood & -1633.43 & & -319.81 & & -1280.08 & \\
\hline Pseudo R-square & 0.084 & & 0.167 & & 0.084 & \\
\hline Observations & 2677 & & 575 & & 2097 & \\
\hline
\end{tabular}

$*, * *$, and $* * *$ indicate statistical significance at the $10 \%, 5 \%$, and $1 \%$ levels for two-tailed tests, respectively.

have discussed in Section 3.2, many CEO turnovers may not be performance-related. Following Dahya et al. (2002) and Fich and Shivdasani (2006), we conduct robustness tests using forced turnovers identified in Section 3.2.
Table 7 reports estimation results for Probit models. As shown in the table, empirical results are consistent with previous findings in terms of sign and significance. The probability of forced turnover is negatively related to both ROA and the lagged ROA. For the full sample, 
Table 7. Probit regression analysis of forced CEO turnover at the publicly listed firms in China

The models are estimated using firm-level data of the firms listed on the Shanghai or Shenzhen stock exchanges in China during the period 1999-2002. State-controlled firms are firms of which the state is the largest shareholder, while non-statecontrolled firms are firms of which the state is not the largest shareholder. The dependent variable is forced CEO turnover. Performance is measured with ROA. Lag(performance) is the one-year lagged performance (ROA). Largest Investor is the percentage of the shares held by the largest investor. CEO age is the age (in years) of the CEO. Duality equals 1 when the CEO holds the board chair position, and zero otherwise. CEO tenure is the number of the years the CEO has held the position till now. Board size is the number of directors on the board. Independent Director is the number of independent directors on the board. No. of Supervisors is the number of supervisors on the supervisory committee. Outside Supervisor is the number of outside supervisors on the supervisory committee. Firm size is the natural logarithm of the total assets. Marketization is the NERI (National Economics Research Institute, China) marketization index that measures the overall market development in each province in China, including market competition, government regulation, and the legal environment. Industry, province and year dummies are included in the models, but their coefficients are not reported. $P$-values for two-tailed tests that the coefficient estimates equal zero are reported. The $P$-values are estimated using robust stand errors that account for potential heteroskedasticity and time series autocorrelation within each company (clustering by company). The coefficient estimates are transformed to represent the marginal effects evaluated at the means of the independent variables from the Probit regression. The marginal effect of a dummy variable is calculated as the discrete change in the expected value of the dependent variable as the dummy variable changes from 0 to 1 .

\begin{tabular}{|c|c|c|c|c|c|c|}
\hline \multirow[t]{2}{*}{ Independent Variables } & \multicolumn{2}{|c|}{ Full Sample } & \multicolumn{2}{|c|}{ State-Control } & \multicolumn{2}{|c|}{ Non-State-Control } \\
\hline & Coefficient & $P$-Value & Coefficient & $P$-Value & Coefficient & $P$-Value \\
\hline Performance & $-0.169 * * *$ & 0.001 & -0.070 & 0.385 & $-0.212 * * *$ & 0.001 \\
\hline Lag Performance & $-0.259 * * *$ & 0.001 & -0.142 & 0.134 & $-0.318 * * *$ & 0.001 \\
\hline Largest Investor & $-0.076^{* *}$ & 0.038 & $-0.151 *$ & 0.066 & $-0.090 * *$ & 0.032 \\
\hline CEO age & $0.002 * *$ & 0.032 & $0.005 * *$ & 0.013 & 0.001 & 0.258 \\
\hline Duality & $-0.039 * *$ & 0.013 & $-0.097 * * *$ & 0.001 & -0.022 & 0.221 \\
\hline CEO tenure & $-0.015 * * *$ & 0.000 & $-0.017 * *$ & 0.013 & $-0.013 * * *$ & 0.001 \\
\hline Board Size & $-0.013 * * *$ & 0.000 & $-0.024 * * *$ & 0.000 & $-0.011 * * *$ & 0.001 \\
\hline Independent Director & $0.023 * * *$ & 0.003 & $0.032 *$ & 0.075 & $0.023 * * *$ & 0.009 \\
\hline No. of Supervisors & $-0.009 *$ & 0.078 & -0.006 & 0.638 & -0.007 & 0.264 \\
\hline Outside Supervisor & 0.008 & 0.106 & -0.004 & 0.711 & $0.010^{*}$ & 0.075 \\
\hline Firm Size & -0.015 & 0.102 & $-0.042 * *$ & 0.040 & -0.006 & 0.574 \\
\hline Marketization & 0.026 & 0.262 & 0.084 & 0.148 & 0.015 & 0.543 \\
\hline Industry Dummies & Yes & & Yes & & Yes & \\
\hline Province Dummies & Yes & & Yes & & Yes & \\
\hline Year Dummies & Yes & & Yes & & Yes & \\
\hline Log-Likelihood & -1524.96 & & -319.86 & & -1277.3 & \\
\hline Pseudo R-square & 0.086 & & 0.167 & & 0.086 & \\
\hline Observations & 2677 & & 575 & & 2097 & \\
\hline
\end{tabular}

a decrease in ROA and lagged ROA by 10 percentage points increases the probability of forced turnover by 0.017 and 0.026 , respectively. For state-controlled firms, the probability of forced CEO turnover is not related to either current or lagged firm performance. In contrast, the probability of forced turnover is significantly related to both current and lagged ROA for nonstate-controlled firms. A decrease in ROA and lagged ROA by 10 percentage points increases the probability of CEO turnover by 0.021 and 0.032 , respectively.
In addition, CEO duality reduces the probability of forced CEO turnover by about 0.1 among non-statecontrolled firms, but does not affect the probability of forced CEO turnover for state-controlled firms. Supervisory committee does not have any impact on the probability of forced CEO turnover for state-controlled firms, but the number of outside supervisors is positively related to the probability of forced turnover. 
Overall, estimation results using forced turnover strengthen our previous findings that state control weakens managerial incentives and internal monitoring schemes.

\section{Empirical evidence on CEO compensation and firm performance}

\subsection{Compensation and performance - basic models and results}

We now examine the impact of state control on managerial pay-performance sensitivity. Brickley and Van Horn (2002) provide evidence that managerial compensation is related to current or lagged firm performance. In China, although some forms of incentive pay such as monthly and quarterly bonuses are distributed within the same calendar year, year-end bonuses are typically distributed at the end of the lunar calendar year, which is often two or three months subsequent to the New Year's day. Therefore, annual managerial compensation might be related to current and lagged firm performance.

To investigate whether and to what extent state control affects the relation between executive compensation and firm performance, we control for firm- and individualspecific factors such as firm age, size, CEO age and $\mathrm{CEO}$ tenure. We also take into account internal governance mechanisms such as board composition and supervisory committee structure, and external governance mechanisms as proxied by provincial marketization index. We then estimate the following panel data regression using fixed effect and random effect methods:

$$
\begin{aligned}
W_{i t}= & \beta_{0 i}+\beta_{1} \text { ROA }_{i t}+\beta_{2} \text { lagROA }_{i t}+\beta_{3} \text { ROA }_{i t} \times \text { State }_{i t}+ \\
& \beta_{4} \text { lagROA }_{i t} \times \text { State }_{i t}+\beta_{5} \text { State }_{i t}+ \\
& \beta_{6} \text { CotrolShareholder }_{i t}+\beta_{7} \text { CEOage }_{i t}+ \\
& \beta_{8} \text { Duality }_{i t}+\beta_{9} \text { CEOtenure }_{i t}+\beta_{10} \text { Boardsize }_{i t}+ \\
& \beta_{11} \text { Ind.Din }_{i t}+\beta_{12} \text { Supervisor }_{i t}+\beta_{13}{\text { Out } . \text { Super }_{i t}+}+ \\
& \beta_{14} \text { Market }_{i t}+\beta_{15} \text { Size }_{i t}+\text { year dummies }+\varepsilon_{i j t},
\end{aligned}
$$

where $W_{i t}$ is the logarithm of annual CEO compensation for firm $i$ at time $t, \beta_{0 i}$ is the firm fixed effect that captures firm-specific unobserved characteristics potentially correlated to regressors ${ }^{16}$.

Table 8 presents fixed effect and random effect estimation results. As shown in the table, CEO compensation is positively related to both current and lagged firm performance. A 1 percentage point increase in ROA and lagged ROA will increase the CEO compensation by $0.836-0.964 \%$ and $0.724-0.955 \%$, indicating that firms provide clear incentives to tie firm performance with executive pay. In addition, there is some evidence that state ownership reduces CEO compensation, as the coefficient for STATE is significantly negative in the random effect model but insignificant in the fixed effect model. The coefficient estimates for the interaction term between lagged performance and state control is negative and statistically significant at the $5 \%$ level in both fixed effect and random effect models while the coefficient estimates for the interaction term between current performance and state control is not statistically significant. The results indicate that state control weakens pay-performance sensitivity, but for lagged performance only. In unreported empirical analyses, we split the full sample into state-controlled and nonstate-controlled firms and estimate the regressions using each sub-sample. We find that CEO compensation is significantly positively related to firm performance for non-state- controlled firms, while insignificant for state-controlled firms. Overall, our results indicate that state control weakens managerial incentive schemes.

Moreover, CEO compensation is negatively related to ownership concentration (the percentage of shares held by the largest shareholder) but positively related to CEO age. Controlling for firm performance, the number of outside supervisors is negatively related to CEO pay. In particular, an additional outside supervisor reduces CEO compensation by $4-5 \%$. Firm size is significantly positively related to CEO compensation in the random effect model. A 10\% increase in firm size increases CEO compensation by $2.2 \%$. Finally, provincial marketization is significantly and positively related to CEO compensation. An increase of marketization index by 1 increases the $\mathrm{CEO}$ compensation by 9-18\%, indicating that CEO compensation is higher in more developed regions in China.

\subsection{Robustness tests - CEO compensation and RPE}

Table 9 contains estimation results for regressions of CEO compensation using RPE as an alternative measure for firm performance.

As shown in the table, CEO compensation is significantly positively related to current and lagged RPE. A 1 percentage point increase in RPE and lagged RPE increases CEO compensation by $0.77-0.96 \%$ and $0.61-0.92 \%$, respectively. In addition, state control has marginally negative impact on CEO compensation in random effect model with interaction term. The coefficient estimates of the interaction term between lagged performance and state control is negative and statistically significant in both the fixed effect and random effect models, while the coefficient estimates of the interaction term between current performance and state control are insignificant. 
Table 8. CEO compensation and firm performance at China's listed firms

This table reports results from firm-level random effects and fixed effects (within) regressions that estimate the impact of firm performance on CEO compensation in different types of companies using firm-level unbalanced panel of the firms listed on the Shanghai or Shenzhen stock exchanges in China during the period 2000-2002. State-controlled firms are firms of which the state is the largest shareholder, while non-state-controlled firms are firms of which the state is not the largest shareholder. The dependent variable is the natural log of total annual compensation of the CEO. Performance is measured with ROA. Largest Investor is the percentage of the shares held by the largest investor. CEO age is the age (in years) of the CEO. Duality equals 1 when the CEO holds the board chair position, and zero otherwise. CEO tenure is the number of the years the CEO has held the position till now. Board size is the number of directors on the board. Independent Director is the number of independent directors on the board. No. of Supervisors is the number of supervisors on the supervisory committee. Outside Supervisor is the number of outside supervisors on the supervisory committee. Firm size is the natural logarithm of the total assets. Marketization is the NERI (National Economics Research Institute, China) marketization index that measures the overall market development in each province in China, including market competition, government regulation, and the legal environment. $P$-values for two-tailed tests that the coefficient estimates equal zero are reported.

\begin{tabular}{|c|c|c|c|c|c|c|c|c|}
\hline \multirow{2}{*}{$\begin{array}{l}\text { Independent } \\
\text { Variables }\end{array}$} & \multicolumn{4}{|c|}{ Firm Fixed Effect } & \multicolumn{4}{|c|}{ Random Effect Estimates } \\
\hline & Coefficient & $P$ & Coefficient & $P$ & Coefficient & $P$ & Coefficient & $P$ \\
\hline Performance & $0.836^{* * *}$ & 0.000 & $0.818^{* * *}$ & 0.003 & $0.964 * * *$ & 0.000 & $0.881 * * *$ & 0.000 \\
\hline $\begin{array}{l}\text { Lag } \\
\text { Performance }\end{array}$ & $0.724 * * *$ & 0.006 & $1.278 * * *$ & 0.000 & $0.955^{* * *}$ & 0.000 & $1.344 * * *$ & 0.000 \\
\hline $\begin{array}{l}\text { Performance } \\
\text { x State }\end{array}$ & & & -0.142 & 0.686 & & & 0.013 & 0.966 \\
\hline $\begin{array}{l}\text { Lag } \\
\text { Performance } \\
\text { x State }\end{array}$ & & & $-1.038 * *$ & 0.026 & & & $-0.792 * *$ & 0.043 \\
\hline State & -0.079 & 0.196 & -0.048 & 0.439 & $-0.072 *$ & 0.088 & -0.049 & 0.264 \\
\hline $\begin{array}{l}\text { Largest } \\
\text { Investor }\end{array}$ & $-0.758^{*}$ & 0.073 & $-0.730^{*}$ & 0.084 & $-0.585 * * *$ & 0.000 & $-0.587 * * *$ & 0.000 \\
\hline CEO age & $0.010^{* *}$ & 0.044 & $0.010^{* *}$ & 0.048 & $0.007 * *$ & 0.016 & $0.007^{* *}$ & 0.014 \\
\hline Duality & -0.040 & 0.461 & -0.042 & 0.439 & 0.009 & 0.842 & 0.007 & 0.873 \\
\hline CEO tenure & -0.022 & 0.180 & -0.019 & 0.252 & 0.000 & 0.969 & 0.000 & 0.987 \\
\hline Board Size & 0.006 & 0.584 & 0.005 & 0.682 & 0.003 & 0.693 & 0.003 & 0.735 \\
\hline $\begin{array}{l}\text { Independent } \\
\text { Director }\end{array}$ & 0.000 & 0.988 & 0.001 & 0.949 & 0.017 & 0.369 & 0.017 & 0.350 \\
\hline $\begin{array}{l}\text { No. of } \\
\text { Supervisors }\end{array}$ & -0.045 & 0.147 & -0.042 & 0.174 & -0.024 & 0.137 & -0.024 & 0.145 \\
\hline $\begin{array}{l}\text { Outside } \\
\text { Supervisor }\end{array}$ & $-0.053^{* * *}$ & 0.004 & $-0.053^{* * *}$ & 0.004 & $-0.040 * * *$ & 0.002 & $-0.04 * * *$ & 0.002 \\
\hline Firm Size & 0.005 & 0.946 & -0.002 & 0.978 & $0.219 * * *$ & 0.000 & $0.216^{* * *}$ & 0.000 \\
\hline Marketization & $0.185^{* * *}$ & 0.000 & $0.185 * * *$ & 0.000 & $0.093 *$ & 0.068 & 0.093* & 0.068 \\
\hline $\begin{array}{l}\text { Industry } \\
\text { Dummies }\end{array}$ & & & & & Yes & & Yes & \\
\hline $\begin{array}{l}\text { Province } \\
\text { Dummies }\end{array}$ & & & & & Yes & & Yes & \\
\hline $\begin{array}{l}\text { Firm Fixed } \\
\text { Effects }\end{array}$ & Yes & & Yes & & & & & \\
\hline Year Dummies & Yes & & Yes & & Yes & & Yes & \\
\hline R-square & & & & & 0.415 & & 0.416 & \\
\hline Observations & 1606 & & 1606 & & 1606 & & 1606 & \\
\hline
\end{tabular}

$*, * *$, and $* * *$ indicate statistical significance at the $10 \%, 5 \%$, and $1 \%$ levels, respectively. 
Table 9. CEO compensation and RPE (relative performance evaluation) at China's listed firms.

This table reports results from firm-level random effect and fixed effect (within) regressions that estimate the impact of RPE on CEO compensation in different types of companies using firm-level unbalanced panel of the firms listed on the Shanghai or Shenzhen stock exchanges in China during the period 2000-2002. State-controlled firms are firms of which the state is the largest shareholder, while non-state-controlled firms are firms of which the state is not the largest shareholder. The dependent variable is the natural log of total annual compensation of the CEO. Performance is measured with RPE: industry median adjusted ROA (firm specific ROA minus the industry median ROA). Lag performance is the one-year lagged industry median adjusted ROA. Largest Investor is the percentage of the shares held by the largest investor. CEO age is the age (in years) of the CEO. Duality equals 1 when the CEO holds the board chair position, and zero otherwise. CEO tenure is the number of the years the CEO has held the position till now. Board size is the number of directors on the board. Independent Director is the number of independent directors on the board. No. of Supervisors is the number of supervisors on the supervisory committee. Outside Supervisor is the number of outside supervisors on the supervisory committee. Firm size is the natural logarithm of the total assets. Marketization is the NERI (National Economics Research Institute, China) marketization index that measures the overall market development in each province in China, including market competition, government regulation, and the legal environment. $P$-values for two-tailed tests that the coefficient estimates equal zero are reported.

\begin{tabular}{|c|c|c|c|c|c|c|c|c|}
\hline \multirow{2}{*}{$\begin{array}{l}\text { Independent } \\
\text { Variables }\end{array}$} & \multicolumn{4}{|c|}{ Firm Fixed Effect } & \multicolumn{4}{|c|}{ Random Effect Estimates } \\
\hline & Coefficient & $P$ & Coefficient & $P$ & Coefficient & $P$ & Coefficient & $P$ \\
\hline Performance & $0.770 * * *$ & 0.000 & $0.733 * * *$ & 0.009 & $0.960 * * *$ & 0.000 & $0.848 * * *$ & 0.000 \\
\hline Lag Performance & $0.610 * * *$ & 0.023 & $1.093 * * *$ & 0.002 & $0.923 * * *$ & 0.000 & $1.260 * * *$ & 0.000 \\
\hline $\begin{array}{l}\text { Performance } \\
\text { x State }\end{array}$ & & & -0.091 & 0.805 & & & 0.105 & 0.747 \\
\hline $\begin{array}{l}\text { Lag Performance } \\
\text { x State }\end{array}$ & & & $-1.000 * *$ & 0.037 & & & $-0.770 *$ & 0.060 \\
\hline State & -0.082 & 0.179 & -0.086 & 0.161 & -0.069 & 0.106 & $-0.070 *$ & 0.098 \\
\hline Largest Investor & $-0.715^{*}$ & 0.091 & -0.687 & 0.105 & $-0.575 * * *$ & 0.000 & $-0.572 * * *$ & 0.000 \\
\hline CEO tenure & -0.024 & 0.148 & -0.021 & 0.198 & 0.000 & 0.966 & 0.000 & 0.988 \\
\hline CEOage & $0.010 * *$ & 0.037 & $0.010 * *$ & 0.041 & $0.007 * *$ & 0.015 & $0.007 * *$ & 0.014 \\
\hline Duality & -0.041 & 0.456 & -0.042 & 0.436 & 0.010 & 0.814 & 0.009 & 0.829 \\
\hline Board Size & 0.006 & 0.582 & 0.004 & 0.686 & 0.003 & 0.719 & 0.002 & 0.774 \\
\hline $\begin{array}{l}\text { Independent } \\
\text { Director }\end{array}$ & 0.000 & 0.987 & 0.001 & 0.952 & 0.016 & 0.397 & 0.016 & 0.382 \\
\hline $\begin{array}{l}\text { No. of } \\
\text { Supervisors }\end{array}$ & -0.047 & 0.129 & -0.044 & 0.153 & -0.025 & 0.132 & -0.024 & 0.138 \\
\hline $\begin{array}{l}\text { Outside } \\
\text { Supervisor }\end{array}$ & $-0.053 * * *$ & 0.004 & $-0.053 * * *$ & 0.004 & $-0.040 * * *$ & 0.002 & $-0.041^{* * *}$ & 0.002 \\
\hline Firm Size & 0.018 & 0.817 & 0.014 & 0.862 & $0.222 * * *$ & 0.000 & $0.221 * * *$ & 0.000 \\
\hline Marketization & $0.184 * * *$ & 0.000 & $0.181 * * *$ & 0.000 & $0.095 *$ & 0.062 & $0.094 *$ & 0.068 \\
\hline Industry Dummies & & & & & Yes & & Yes & \\
\hline $\begin{array}{l}\text { Province } \\
\text { Dummies }\end{array}$ & & & & & Yes & & Yes & \\
\hline $\begin{array}{l}\text { Firm Fixed } \\
\text { Effects }\end{array}$ & Yes & & Yes & & & & & \\
\hline Year Dummies & Yes & & Yes & & Yes & & Yes & \\
\hline R-square & & & & & 0.416 & & 0.416 & \\
\hline Observations & 1606 & & 1606 & & 1606 & & 1606 & \\
\hline
\end{tabular}

$*, * *$, and $* * *$ indicate statistical significance at the $10 \%, 5 \%$, and $1 \%$ levels for two-tailed tests, respectively. 
This provides some evidence that state control weakens managerial incentives by reducing the pay-performance sensitivity. Furthermore, CEO compensation is negatively related to ownership concentration but positively related to CEO age. Controlling for firm performance, the number of outside supervisors is negatively related to firm performance. Firm size is significantly positively related to CEO compensation, but in random effect models only. As before, the degree of provincial marketization is significantly positively related to CEO compensation. An increase of marketization index by 1 increases CEO compensation by $9-18 \%$.

\section{Conclusion}

Numerous empirical studies on privatization find evidence that private ownership is associated with better firm performance than state ownership is. However, there is a long-standing theoretical debate on links between ownership and incentives. This study adds to the debate by providing empirical evidence on whether and to what extent state ownership and control affects managerial incentives among partially privatized firms in China.

Using data from a large sample of publicly listed firms in China during 1999-2002, we find that both CEO turnover and CEO compensation are related to firm performance as measured by ROA and RPE, suggesting that firms provide clear performance-based incentives to motivate CEOs. Furthermore, the likelihood of CEO turnover is not related to either current or lagged firm performance for state-controlled firms while it is significantly negatively related to both current and lagged firm performance for non-state-controlled firms. The results are robust to performance measures and turnover classifications. Moreover, state ownership is associated with lower pay-performance sensitivities in both fixed effect and random effect models of managerial compensation. Overall, empirical results based on Chinese data render support to the theory that state ownership and control weaken managerial incentives, and can partially explain the inefficiency of state ownership found in previous studies, e.g. Xu and Wang (1999), Sun and Tong (2003) and Wei et al. (2005).

We also explore the relation between state control and the effectiveness of internal governance mechanisms such as board composition and supervisory committee. We find that the number of independent directors and outside supervisors do not have significant impact on CEO turnover among state-controlled firms. In contrast, the number of independent directors and outside supervisors are significantly and positively related to the probability of CEO turnover among non-state- controlled firms. In addition, CEO duality reduces the probability of CEO turnover by a much larger magnitude among state-controlled firms, indicating that statecontrolled firms are subject to more severe management entrenchment problems. Furthermore, our results show that state ownership and control also weaken the effectiveness of board and supervisory committee.

\section{Endnotes}

1 According to Megginson (2005), the cumulative value raised through privatization in more than 100 countries now probably exceeds 1.5 trillion. In the transition economies, more than 150,000 large enterprises have experienced revolutionary changes in ownership and economic environment over the past decade (Djankov and Murrell 2002).

2 Tirole (2001) defined corporate governance as the design of institutions that induce or force management to internalize the welfare of stakeholders. The control structure and provision of managerial incentives are regarded as the most important factors to induce or force the internalization. Cragg and Dyck (2003) examine the impact of privatization on pay-performance sensitivity in 112 privatized firms in the U.K. They find that there is no relationship between compensation and firm performance in SOEs but strong pay-performance sensitivity in privatized firms both before and after corporate governance reforms.

3 China Securities Regulatory Commission (CSRC) uses financial performance as an important criterion in determining an SOE's eligibility for the stock market. An SOE must report three consecutive years of profits before applying for an IPO; and listed companies that report three consecutive years of losses will be delisted from the stock exchange.

4 As of February 2006, shares of over 100 publicly listed firms have moved from "partially tradable" to "fully tradable", or have become the so-called "G shares". During this process, the holders of non-tradable shares have agreed to provide the holders of tradable shares with free shares, cash, warrants or some other means of compensation in exchange for their shares to become tradable.

5 In China many SOEs carve out their most profitable assets and businesses into a joint stock company for the IPO in order to raise capital in the stock market. As a result, many listed firms in China have their parent companies as controlling shareholders. CEOs of these firms can be assigned by parent companies, and their turnover can be due to a change in their work assignment. The large proportion of CEO turnover reported as change in work assignment represents a unique feature of the Chinese context.

6 Our search is based on three data resources: the annual reports of the firms, CSMAR database and the information of China's listed firms available at http://www.jrj.com.cn.

7 Firms usually report compensations for the top three executives, including total annual compensation for CEOs 
and two other highest-paid executives (often vice CEOs). We use the average compensation for the top three executives to proxy for CEO compensation in this study. We compile compensation data from annual reports of listed firms during the period years 2000-2002. The data for the year 1999 are not included due to numerous missing observations.

8 With approval from the CSRC, a company can issue employee shares to managers and employees, typically at a significant discount, at the time of Initial Public Offering (IPO). Employee shares are not tradable in the stock exchanges, although some companies have established Shareholding Association or Workers' Union to buy back shares in case that an employee retires, resigns, gets fired or dies. In such cases, employee shares are generally priced on the basis of their net asset value and determined by managers.

9 Stock return is another frequently used performance measure. However, for the following reasons, it is not used in this study. First, the majority of shares in China's listed firms is held by the state and legal entities and not tradable. Hence, firm profitability would be more important than stock return in evaluating managerial performance. Second, changes in stock prices are poor indicators of changes in firm fundamental values in China (Allen et al. 2005). Morck et al. (2000) find that more than $80 \%$ of stocks listed on the two exchanges in China move in the same direction in a given week, which suggests that stock returns are not informative of firm performance, because stock returns tend to reflect market-wide information rather than firm-specific information. Despite the above arguments, we use stock returns as a performance measure in robustness analysis and find that it has no impact on CEO turnover and compensation.

10 According to the Company Law, a board of directors should consist of 5 to 19 directors. The average board size in our sample is 9.6.

${ }^{11}$ According to the "Guidelines for Establishing Independent Director System in Listed Firms", prerequisites for independent director include: (a) neither the individual not his relatives work for the listed firms or its subsidiaries; (b) the individual does not directly or indirectly own more than $1 \%$ of shares of the listed firm; (c) neither the individual nor his close relatives (including parents, spouses and children) work for one of the largest 5 shareholders or a shareholder that owns more than $5 \%$ of shares of the listed firm.

$12 \mathrm{Ai}$ and Norton (2003) reviewed 73 published papers on JSTOR between 1980 and 1999 and found that none of the studies interpreted the coefficient on the interaction term correctly. Similarly, Powers (2005) surveyed 38 papers in the finance field, only 5 of them interpret the results appropriately.

13 The reported p-values are estimated using robust stand errors that account for potential heteroskedasticity and time series autocorrelation within each company (clustering by company). The coefficient estimates are transformed to simplify their economic interpretation. In Table 5, the reported coefficients represent marginal effects evaluated at the means of the independent variables from the Probit regression. The marginal effect of a dummy variable is calculated as the discrete change in the expected value of the dependent variable when the dummy variable changes from 0 to 1 .

14 According to the "Code of Corporate Governance for Listed Firms in China" issued by the CSRC, a controlling shareholder makes recommendations to the board of directors regarding the appointment of directors. The shareholders' meeting votes on whether to accept the recommendations. Thus the key player in the appointment of top managers is the controlling shareholder (Firth et al. 2006).

15 Shleifer and Vishny (1997) point out that, "as ownership gets beyond a certain point, the large owners gain nearly full control and are wealthy enough to prefer using firms to generate private benefits of control that are not shared by minority shareholders".

16 The rationale for presenting the random effect results together with the fixed effect results is that controlling for firm fixed effect may reduce the significance of the coefficients because the coefficients are derived based on the within-firm changes of variable such as ownership structure, governance structure and firm size, which may be relatively constant over a short time period. In fact, for most panel data, particularly short panels such as this ( 3 years in our case), most of the variation of the data is in the cross-sectional dimension. Applying a fixed effect model not only eliminates the invisible firm specific characteristics but also wipes out useful inter-firm variation, which may account for most of the total variation (Zhou 2001).

\section{References}

Ai, C.; Norton, E. 2003. Interactive terms in non-linear models, Economics Letters 80: 123-129. doi:10.1016/S0165-1765(03)00032-6

Alas, R. 2003. Consequences of socialism in employee's attitudes, Journal of Business Economics and Management 4(1): 45-52.

Alchian, A. 1965. Some economics of property rights, $\mathrm{Po}-$ litico 30: 816-829.

Allen, F.; Qian, J.; Qian, M. 2005. Law, finance, and economic growth in China, Journal of Financial Economics 77: 57-116. doi:10.1016/j.jfineco.2004.06.010

Boycko, M.; Shleifer, A.; Vishny, R. 1996. A theory of privatization, Economic Journal 106: 309-319. doi: $10.2307 / 2235248$

Boubakri, N.; Cosset, J.-C. 1998. The financial and operating performance of newly privatized firms: evidence from developing countries, Journal of Finance 53: 1081-1110. doi:10.1111/0022-1082.00044 
Brickley, J. A.; Van Horn, L. 2002. Managerial incentives in nonprofit organizations: Evidence from hospitals, Journal of Law and Economics 45: 227-249. doi:10.1086/339493

Chang, E. C. and Wong, M. L. 2004. Political control and firm performance in China's listed firms, Journal of Comparative Economics 32: 617-636. doi:10.1016/j.jce.2004.08.001

Cragg, M. I.; Dyck, I. J. A. 2003. Privatization and management incentives: Evidence from the United Kingdom, Journal of Law, Economics \& Organization 19: 176-218. doi:10.1093/jleo/19.1.176

Dahya, J.; McConnell, J. J.; Travlos, N. G. 2002. The Cadbury committee, corporate performance, and top management turnover, Journal of Finance 57: 461-483. doi:10.1111/1540-6261.00428

Dalton, D.; Kesner, I. 1997. Composition and CEO duality in boards of directors: An international perspective, Journal of International Business Studies 18: 33-42.

doi:10.1057/palgrave.jibs.8490410

Djankov, S.; Murrell, P. 2002. Enterprise restructuring in transition: a quantitative survey, Journal of Economic Literature 40: 739-792. doi:10.1257/002205102760273788

D'Souza, J.; Megginson, W. 1999. The financial and operating performance of privatized firms during the 1990s, Journal of Finance 54: 1397-1438.

doi:10.1111/0022-1082.00150

Estrin, S. 2002. Competition and corporate governance in transition, Journal of Economic Perspectives 16: 101-124. doi:10.1257/0895330027139

Fama, E.; Jensen, M. 1983. Separation of ownership and control, Journal of Law and Economics 26: 301-325. doi:10.1086/467037

Fan, G.; Wang, X. L. 2004. NERI Index of marketization of China's provinces. Economics Science Press (in Chinese).

Fich, E.; Shivdasani, A. 2006. Are busy boards effective monitors? Journal of Finance 61: 689-724.

doi:10.1111/j.1540-6261.2006.00852.x

Firth, M.; Fung, M.Y.; Rui, O.M. 2006. Corporate performance and CEO compensation in China, Journal of Corporate Finance 12(4): 693-714. doi:10.1016/j.jcorpfin.2005.03.002

Fleisher, B. M.; Wang, X. 2003. Potential residual and relative wages in Chinese township and village enterprises, Journal of Comparative Economics 31: 429-443.

doi:10.1016/S0147-5967(03)00071-4

Grossman, S.; Hart, O. 1986. The costs and benefits of ownership: A theory of lateral and vertical integration, Journal of Political Economy 94: 691-719. doi:10.1086/261404

Groves, T.; Hong, Y.; McMillan, J.; Naughton, B. 1995. China's evolving managerial labor market, Journal of Political Economy 103: 873-892. doi:10.1086/262006

Gupta, N. 2005. Partial privatization and firm performance, Journal of Finance 60: 987-1015.

doi:10.1111/j.1540-6261.2005.00753.x

Hadlock, C. J.; Lumer, G. B. 1997. Compensation, turnover, and top management incentives: Historical evidence, Journal of Business 70: 153-187. doi:10.1086/209714
Huson, M. R.; Parrino, R.; Starks, L. T. 2001. Internal monitoring mechanisms and CEO turnover: A long-term perspective, Journal of Finance 56: 2265-2297. doi:10.1111/0022-1082.00405

Huson, M. R.; Malatesta, P. H.; Parrino, R. 2004. Managerial succession and firm performance, Journal of Financial Economics 74: 237-275. doi:10.1016/j.jfineco.2003.08.002

Jensen, M. 1993. The modern industrial revolution, exit, and the failure of internal controlling systems, Journal of Finance 48: 831-880. doi:10.2307/2329018

Kaplan, S. 1994. Top executive rewards and firm performance: A Comparison of Japan and the United States, Journal of Political Economy 102: 510-546. doi:10.1086/261944

Kornai, J. 1998. The place of the soft budget constraint syndrome in economic theory, Journal of Comparative Economics 26: 11-17. doi:10.1006/jcec.1997.1505

Laffont, J.-J. and Tirole, J. 1993. A theory of incentives in procurement and regulation. MIT press.

Lin, J.; Cai, F.; Li, Z. 1998. Competition, policy burdens, and state-owned enterprise reform, American Economic Review 88: 422-427.

Megginson, W. 2005. The financial economics of privatization. Oxford University Press. doi:10.1093/0195150627.001.0001

Megginson, W.; Netter, J. N. 2001. From state to market: a survey of empirical studies on privatization, Journal of Economic Literature 39: 321-389.

Mengistae, T.; Xu, L. C. 2004. Agency theory and executive compensation: The case of Chinese state-owned enterprises, Journal of Labor Economics 22: 615-637. doi:10.1086/383109

Morck, R.; Yueng, B.; Yu, W. 2000. The information content of stock market: why do emerging markets have synchronous stock price movement? Journal of Financial Economics 58: 215-220. doi:10.1016/S0304-405X(00)00071-4

Parrino, R. 1997. CEO turnover and outside succession: A cross-sectional analysis, Journal of Financial Economics 46: 165-197. doi:10.1016/S0304-405X(97)00028-7

Powers, E. 2005. Interpreting logit regression with interactive terms: an application to the management turnover literature, Journal of Corporate Finance 11: 504-522. doi:10.1016/j.jcorpfin.2004.08.003

Prendergast, C. 1999. The provision of incentives in firms, Journal of Economic Literature 37: 7-63.

Shirley, M.; Xu, L. C. 1998. Information, incentives and commitment: An empirical analysis of contracts between government and State enterprises, Journal of Law, Economic \& Organization 14: 358-378. doi:10.1093/jleo/14.2.358

Shleifer, A. 1998. State versus private ownership, Journal of Economic Perspectives 12: 133-150.

Shleifer, A.; Vishny, R. 1994. Politicians and firms, Quarterly Journal of Economics 109: 995-1025. doi:10.2307/2118354

Shleifer, A.; Vishny, R. 1997. A survey of corporate governance, Journal of Finance 52: 737-777. doi:10.2307/2329497 
$\mathrm{Su}$, D. 2005. Corporate finance and state enterprise reform in China, China Economic Review 16: 118-148. doi:10.1016/j.chieco.2004.09.003

Sun, Q.; Tong, W. 2003. China share issue privatization: the extent of its success, Journal of Financial Economics 70: 183-222. doi:10.1016/S0304-405X(03)00145-4

Tirole, J. 2001. Corporate governance, Econometrica 69: 1-35. doi:10.1111/1468-0262.00177

Tvaronavičienė, M. 2004. Theoretical framework for restructuring of transition countries, Journal of Business Economics and Management 5(2): 53-59.

Tvaronavičienè, M.; Kalašinskaite, K. 2005. Analysis of privatization: Different approaches, Journal of Business Economics and Management 6(1): 53-59.

Vickers, J.; Yarrow, G. 1991. Economic perspectives on privatization, Journal of Economic Perspectives 5: 111-132.
Wei, Z.; Xie, F.; Zhang, S. 2005. Ownership structure and firm value in China's privatized firms: 1991-2001, Journal of Financial and Quantitative Analysis 40: 87-108. doi:10.1017/S0022109000001757

Xu, X.; Wang, Y. 1999. Ownership structure and corporate governance in Chinese stock companies, China Economic Review 10: 75-98. doi:10.1016/S1043-951X(99)00006-1

Yermak, D. 1996. Higher market valuation for firms with a small board of directors, Journal of Financial Economics 40: 185-211. doi:10.1016/0304-405X(95)00844-5

Zhou, X. 2001. Understanding the determinants of managerial ownership and the link between ownership and performance: comment, Journal of Financial Economics 62: 559-571. doi:10.1016/S0304-405X(01)00085-X 